\title{
KONTRIBUSI KEKUATAN OTOT LENGAN TERHADAP HASIL SERVIS BAWAH BOLAVOLI DI SMP NEGERI 2 RAMBAH SAMO KABUPATEN ROKAN HULU
}

\author{
Joni Alpen \\ Universitas Islam Riau \\ Email: alpenbungsu@yahoo.co.id
}

\begin{abstract}
ABSTRAK
Penelitian ini berpangkal dari beberapa permasalahan yang ditemukan peneliti di lapangan, yang telah dilakukan di SMP Negeri 2 Rambah Samo Kabupaten Rokan Hulu pada saat melakukan servis bawah, sikap awal berdiri sudah terlihat kesalahan yang menonjol, kaki yang dirapatkan sehingga tidak leluasa untuk bergerak dalam melakukan servis bawah. Sikap badan yang tidak merunduk saat melakukan servis bawah sehingga siswa terlihat kaku. Terkadang bola dilambung terlalu tinggi pada saat melakukan servis bawah, sehingga perkenaan kontak tangan dengan bola kurang tepat. Pandangan ke arah bola tidak diseimbangkan dengan ayunan lengan tangan terhadap bola. sehingga bola tidak dapat diarahkan sesuai dengan yang diharapkan. Pada sikap perkenaan, masih terdapat kesalahan yaitu, siswa belum bisa secara maksimal menyesuaikan ketepatan tangan saat menyentuh bola. Kemudian pada sikap akhir dalam servis bawah, ada siswa tidak kembali pada posisi awal setelah melakukan servis bawah. Tujuan penelitian ini adalah untuk mengetahui kontribusi kekuatan otot lengan terhadap kemampuan servis bawah bolavoli siswa SMP Negeri 2 Rambah Samo Kabupaten Rokan Hulu. Jenis penelitian ini merupakan korelasi. Semua populasi diambil sebagai sampel, teknik ini disebut dengan total sampling. Jadi populasi dan sampel di penelitian ini adalah siswa kelas VIII SMP Negeri 2 Rambah Samo Kabupaten Rokan Hulu sebanyak 40 orang. Pengumpulan data ini dilakukan dengan test push-up dan tes servis bawah bolavoli. Berdasarkan hasil pengolahan data diperoleh $r_{\text {hitung }}$ sebesar 84.03 sedangkan $r_{\text {tabel }}$ pada taraf signifikan $5 \%$ adalah 0.304 , dari data tersebut, maka uraian tersebut dapat ditarik asumsinya bahwa $r_{\text {hitung }} \geq r_{\text {tabel }}$ atau $84.03 \geq 0.304$. Dengan demikian dapat disimpulkan bahwa terdapat kontribusi $7.06 \%$ dan terdapat signifikan antara kekuatan otot lengan terhadap hasil servis bawah bolavoli siswa SMP Negeri 2 Rambah Samo Kabupaten Rokan Hulu.
\end{abstract}

Kata Kunci: Kekuatan Otot Lengan, Hasil Servis Bawah Bolavoli

\begin{abstract}
This research stemmed from a few issues that were found in the field, researchers have done in junior high Country 2 Rambah Samo Rokan Hulu at the time of service, the initial attitude stands already seen errors stand out, a walk to a point so that it does not move freely in doing Services down. The attitude of the Agency is not ducking when performing Services under so that students look stiff. Sometimes the ball too high dilambung at the time of service, so contact perkenaan hands with the ball less precisely. Pandangan towards the ball is not balanced with swing arm hand against the ball so that the ball can't. routed as expected. On the attitude of perkenaan, there is still an error i.e., students have not been able to optimally adjust the precision hand while touching the ball. Then at the end in an attitude of service, there are no students back in the initial position after performing service under. The purpose of this research is to know the contribution of muscle strength of the arm against the capabilities of the services under the State Junior High School students volleyball 2 Rambah Samo Rokan Hulu. This type of research is a correlation. All of the population taken as samples, this technique is referred to
\end{abstract}


as total sampling. So populations and samples in this research is grade VIII SMP Negeri 2 Rambah Samo Rokan Hulu as many as 40 people. Data collection was carried out with test push-up test and servicing under volleyball. Based on the results of the processing of data obtained $r_{\text {count }}$ of 84.03 whereas $r_{\text {table }}$ on a significant level of $5 \%$ is 0304 , from these data, then such descriptions can be drawn the assumption that $r_{\text {count }} \geq r_{\text {table }}$ or $84.03 \geq 0304$. Thus it can be concluded that there is a contribution of $7.06 \%$ and there is significant between the muscle strength of the arm against the results of the services under State Volleyball JUNIOR HIGH students 2 Rambah Samo Rokan Hulu.

Keyword : Strenght Muscle Arm Against, Result Underhand Service Volleyballs

\section{PENDAHULUAN}

Manusia sebagai individu yang merupakan gabungan dua undur terdiri atas jasmani dan rohani, dari kedua unsur tersebut satu sama lain tidak dapat dipisahkan dan merupakan satu kesatuan yang utuh, maka kedua unsur tersebut harus dibina, disempurnakan, dan dipelihara dengan baik agar terwujud individu yang utuh. Berdasarkan kesatuan kedua unsur tersebut, dalam usaha menunjang tercapainya pendidikan Nasional tidak hanya ditentukan oleh kemampuan intelektual saja, namun ditentukan oleh kemampuan jasmani yang memadai.

Perkembangan ilmu pengetahuan banyak memberikan perubahan yang signifikan terhadap kesejahteraan manusia. Hal itu terlihat dari banyaknya penemuan yang merupakan hasil karya, cipta dan rasa manusia. Semua itu tentu tidak terlepas dari pendidikan yang dijalani. Pendidikan merupakan bidang yang memegang peranan paling penting dalam usaha membangun manusia Indonesia seutuhnya.

Pendidikan jasmani sebagai bagian integral dari proses pendidikan secara keseluruhan. Pendidikan jasmani mempunyai peran unik di banding bidang studi lain, karena melalui penjas selain dapat digunakan untuk pengembangan aspek fisik dan psikomotor, juga ikut berperan dalam pengembangan aspek kognitif dan afektif secara serasi dan seimbang. Pendidikan jasmani dan kesehatan merupakan proses pendidikan yang memanfaatkan aktivitas fisik dan kesehatan untuk menghasilkan perubahan holistik dalam kualitas individu, baik dalam hal fisik, psikis, mental, serta emosional.

Pada kenyataannya, pendidikan jasmani dan kesehatan adalah suatu bidang kajian yang sungguh luas. Titik perhatiannya adalah peningkatan gerak manusia. Lebih khusus lagi, pendidikan jasmani dan kesehatan berkaitan dengan hubungan antara gerak manusia dan wilayah pendidikan lainnya, hubungan dari perkembangan tubuh-fisik dengan pikiran dan jiwanya. Berbicara mengenai kesegaran jasmani dalam upaya peningkatan kualitas fisik memang merupakan permasalahan yang menarik.

Akan tetapi kalau keterpaduan pembinaan kesegaran jasmani dapat berjalan dengan baik dan ada komitmen dari pemerintah tidak mustahil bahwa pembinaan kesegaran jasmani akan berhasil dengan baik. Semakin banyak masyarakat melakukan latihan jasmani, berarti semakin berhasil pembinaan kesegaran jasmani dan tingkat kesegaran jasmani masyarakat semakin baik serta akan meningkatkan kualitas fisik manusia. Pendidikan jasmani pendidikan yang memanfaatkan aktivitas jasmani yang direncanakan secara sistematik bertujuan untuk mengembangkan dan meningkatkan individu secara organik, neuromuskuler, perseptual, kognitif dan emosional dalam kerangka sistem pendidikan Nasional. Pendidikan jasmani adalah kegiatan jasmani yang diselenggarakan untuk menjadi media bagi kegiatan pendidikan dalam olahraga. 
Olahraga adalah salah satu bentuk dari upaya peningkatan kualitas manusia Indonesia melalui fisiknya yang diarahkan pada pembentukan watak dan kepribadian, disiplin dan sportivitas yang tinggi, serta peningkatan prestasi yang dapat membangkitkan rasa kebanggaan Nasional (GBHN Tap MPR No. II/MPR/1988). Dalam olahraga dikenal berbagai macam cabang olahraga, salah satunya adalah cabang bolavoli.

Permainan bolavoli dapat digunakan sebagai sarana untuk mendidik, sebab dengan olahraga bolavoli dapat membentuk pribadi yang sportif, jujur, kerjasama, tanggung jawab, yang semua itu merupakan nilai-nilai pendidikan yang dapat ditanamkan. Oleh karena itu, olahraga permaina bolavoli diberikan di lingkungan sekolah, bolavoli diberikan sejak anak-anak SD, SLTP, SMA sampai ditingkat perguruan tinggi.

Perkembangan teknik dasar diarahkan pada peningkatan keterampilan gerak yang dimilki oleh siswa. Suhadi dan Sujarwo juga mengemukakan bahwa "teknik dasar merupakan suatu gerak dasar yang harus dimiliki oleh seorang pemain bolavoli baik dalam gerakan kaki dan juga gerakan tubuhnya". Sujarwo (2009)

Bolavoli merupakan salah satu cabang olahraga dari bermacam ragam banyaknya olahraga yang ada dimuka bumi ini. Permaian ini dimainkan oleh dua regu yang masing-masing regu mempunyai pemain berjumlah enam orang yang dipisahkan oleh net. dan dipimpin oleh satu orang wasit pertama yang berada diatas, satu orang wasit kedua dibawah dengan posisi berhadapan dengan wasit satu dan dibantu oleh empat hakim garis yang masing-masing berdiri diluar garis. Awalnya permainan bolavoli adalah permainan rekreasi, tetapi setelah banyaknya perubahan dan perkembangan kata rekreasi itu berubah menjadi jenjang prestasi yang bisa membawa harkat dan martabat bangsa bahkan bisa mengharumkan nama baik Negara.

Permainan bolavoli diciptakan oleh William G. Morgan di kota Holyoke, Amerika Serikat. Pada mulanya permainan ini dimainkan hanya untuk penyegaran jasmani. Karena waktu itu William G. Morgan merupakan seorang pembina dalam pendidikan jasmani pada asosiasi pemuda yang bernama Young Men Christian Association (YMCA). Permainan bola voli ini sangat berkembang pesat di Amerika Serikat,

Permainan bolavoli merupakan permainan yang mudah untuk dimainkan semua kalangan baik itu anak-anak, remaja maupun tingkat dewasa. Namun demikian di dalam permainan bolavoli ini perlu menguasai beberapa teknik dasar baik itu servis, pasing, smash dan blok. Dengan menguasai teknik tentu terciptalah permainan yang menyenangkan. Teknik dasar merupakan hal yang wajib dikuasai dalam permainan bolavoli. Salah satu teknik dasar permainan bolavoli adalah servis.

Pukulan servis dilakukan pada permulaan dan setelah terjadinya suatu kesalahan, dan ini dapat menjadi serangan pertama bila bola yang dipukul keras dan terarah. Servis harus dilakukan dengan baik dan sempurna oleh semua pemain, karena kesalahan servis mengakibatkan pertambahan angka bagi lawan. Demikian pentingnya kedudukan servis dalam permianan bolavoli maka teknik dasar servis harus dikuasai dengan baik. Latihan dasar servis sebaiknya mendapat porsi yang cukup dan sesuai dengan tingkat usia, sehingga dapat mencapai hasil yang maksimal.

Rangkaian servis bawah tampaknya merupakan gerakan yang sederhana dan sangat mudah dilihat untuk melakukannya, hanya dengan melambung bola lalu dipukul untuk melakukan servis. Tetapi untuk dapat melakukan servis bawah dengan baik, gerakan di atas saja tidak cukup, masih diperlukan unsur lain untuk menyempurnakan 
gerakan dalam melakukan keterampilan servis bawah seperti sikap awalan, baik sikap berdiri, sikap badan, maupun sikap tangan dan sikap pandangan.

Syafruddin (2013:71) kekuatan merupakan kemampuan otot atau tarik menarik otot untuk mengatasi beban atau tahanan (resistance) baik beban dalam tubuh sendiri maupun beban dari luar. Menurut Erianti (2007: 81) secara fisiologis (ilmu faal) kekuatan merupakan kemampuan otot mengatasi beban atau latihan, sedangkan secara ilmu fisika kekuatan merupakan hasil perkalian antara massa dengan percepatan (acceleration).

Salah satu yang harus diperhatikan dalam teknik dasar adalah penguasaan teknik dasar servis bawah. Di dalam melakukan gerakan servis bawah dengan sempurna dibutuhkan kekuatan otot yang baik, posisi badan yang baik dan kondisi fisik yang baik pula. Diawali dengan kekuatan otot lengan yang baik untuk melakukan daya dorongan dilanjutkan ayunan lengan yang panjang akan menghasilkan pukulan yang lebih kuat. Kekuatan otot lengan yang baik memberikan dampak positif berkaitan dengan penggunaan daya dalam melakukan suatu pukulan. Dengan memiliki daya yang lebih besar, maka akan lebih menguntungkan pada saat akan memukul bola.

Misalnya pada saat melakukan servis bawah, sikap awal berdiri sudah terlihat kesalahan yang menonjol, kaki yang dirapatkan sehingga tidak leluasa untuk bergerak dalam melakukan servis bawah. Sikap badan yang tidak merunduk saat melakukan servis bawah sehingga siswa terlihat kaku. Terkadang bola dilambung terlalu tinggi pada saat melakukan servis bawah, sehingga perkenaan kontak tangan dengan bola kurang tepat.

Pandangan ke arah bola tidak di seimbangkan dengan ayunan lengan tangan terhadap bola. sehingga bola tidak dapat diarahkan sesuai dengan yang diharapkan. Pada sikap perkenaan, masih terdapat kesalahan yaitu, siswa belum bisa secara maksimal menyesuaikan ketepatan tangan saat menyentuh bola. Kemudian pada sikap akhir dalam servis bawah, ada siswa tidak kembali pada posisi awal setelah melakukan servis bawah.

Kekuatan adalah tegangan kontaksi otot yang dicapai dalam sekali usaha maksimal. Usaha maksimal ini dilakukan oleh otot atau sekelompok otot untuk mengatasi tahanan. Kekuatan merupakan unsur yang sangat penting dalam aktifitas olahraga. Karena kekuatan merupakan daya penggerak dan pencegah cedera. Selain itu kekuatan memainkan peranan penting dalam komponen-komponen kemampuan fisik yang lainnya di antaranya power, kelincahan, dan ketepatan. Dengan demikian kekuatan merupakan faktor utama dalam menciptakan prestasi yang optimal. Ismaryati (2006)

Kekuatan lengan adalah gerakan yang dilakukan secara eksplosif. Maksudnya, kemampuan seseorang untuk mempergunakan kekuatan otot lengan yang dikerahkan secara maksimum dalam waktu sependek-pendeknya ketika melakukan passing bawah dalam olahraga bolavoli. Gerakan passing bawah banyak didominasi oleh gerakan otot lengan. Oleh karena itu, perlu koordinasi gerak yang baik dari gerakan seperti pada passing bawah. Dengan demikian, semakin cepat gerakan itu dilakukan maka semakin banyak pula komponen gerakan yang harus dikoordinasikan.

Dari sekian banyak teknik dasar yang ada, passing bawah merupakan teknik yang selalu digunakan untuk menerima bola dari pukulan servis lawan dan bertahan jika ada serangan atau smash. Permainan bolavoli merupakan permainan cepat yang selalu menggunakan teknik passing bawah yang dominan dibandingkan dengan teknik yang 
lain. Selain kekuatan otot lengan, panjang lengan mempunyai hubungan dengan hasil servis bawah bolavoli.

Hal ini disebabkan bahwa gerakan servis merupakan gerakan ayunan lengan yang berpangkal pada pangkal lengan dalam memberikan kekuatan pukulan saat mengenai bola. Di samping kekuatan dan panjang lengan, kordinasi mata tangan juga mempengaruhi servis bawah. Dengan kordinasi yang baik saat melakukan sebuah servis maka akan menambah ketepatan pada arah laju bola. Namun pada kenyataannya sedikit siswa yang masih kurang dalam melakukan servis bawah dengan baik dan tidak sampai pada sasaran.

\section{METODE PENELITIAN}

Penelitian ini digolongkan pada jenis penelitian kuantitatif dengan menggunakan rancangan penelitian korelasional. Sesuai dengan permasalahan yang terdapat pada bagian yang telah di uraikan maka penelitian ini termasuk jenis korelasi, variabelvariabel yang ada pada penelitian ini yakni kekuatan otot lengan sebagai variabel bebas, sedangkan ketepatan servis bawah bolavoli sebagai variabel terikat.

Penelitian korelasi sering disebut dengan penelitian sebab akibat (kausal korelation). Tujuan penelitian ini untuk mengetahui hubungan antara dua variable atau lebih, atau hubungan antara variable bebas dengan variable terikat, Sugiyono (2010:43). Dalam penelitian ini penulis menggunakan bentuk hubungan korelasional kausal yaitu $\mathrm{X}$ mempengaruhi $\mathrm{Y}$ atau sebaliknya $\mathrm{Y}$ mempengaruhi $\mathrm{X}$.

Populasi dalam penelitian adalah seluruh siswa kelas VIII SMP Negeri 2 Rambah Samo Kabupaten Rokan Hulu dengan jumlah siswa 78 dengan jumlah laki-laki 40 dan perempuan 38. Sampel dalam penelitian ini ditetatpkan hanya siswa laki-laki kelas VIII SMP Negeri 2 Rambah Samo Kabupaten Rokan Hulu yang berjumlah 40 siswa dengan teknik purposive rondom sampling.

\section{a. Tes Kekuatan Otot Lengan}

Tes kekuatan adalah tes yang bertujuan untuk mengukur otot lengan dan bahu, tetapi yang mendapatkan tekanan yaitu otot lengan. Prosedur pelaksanaan tes kekuatan otot lengan dilakukan dengan gerakkan Push-Up Test (Modified). Tetapi kriteria test yang baik juga harus mengandung unsur-unsur pendidikan, menurut Arsil dan Adnan (2006: 23) yang tidak kalah penting, karena test lebih mengarah untuk tujuan pendidikan jasmani, maka tes yang digunakan mengandung unsur-unsur pendidikan jasmani yang memuat kognitif, psikomotor dan afektif.

\section{b. Tes Kemampuan Servis Bawah Bolavoli}

Yang dimaksud dengan tes servis adalah suatu alat pengukur yang digunakan untuk mengukur kemampuan mengarahkan bola service ke arah sasaran dengan tepat dan terarah, Nurhasan (2001: 170).

\section{HASIL DAN PEMBAHASAN}

Berdasarkan penjelasan dan uraian yang telah dibuat dan dikumpulkan sebelumnya, maka dalam bab ini akan dilakukan analisis dan pembahasan yang di peroleh dalam penelitian ini. Hasil penelitian ini akan dijabarkan sesuai dengan tujuan dan hipotesis yang telah di ajukan sebelumnya. Adapun hasil deskripsi data dari hasil tes pengukuran antara kontribusi kekuatan otot lengan (variabel $\mathrm{X}$ ) dan hasil servis bawah bolavoli (variabel Y) adalah sebagai berikut. 


\section{Deskripsi kekuatan otot lengan siswa SMP Negeri 2 Rambah Samo Kabupaten Rokan Hulu}

Dari hasil tes yang dilakukan untuk mengetahui kekuatan otot lengan adalah dengan push-up. Setiap siswa mendapatkan giliran sebanyak satu kali tes. Tes dihitung dari sebanyak siswa melakukan push-up. Penilaian diambil dari kesanggupan siswa melakukan push-up untuk diambil sebagai skor kekuatan otot lengan. Berdasarkan hasil tes yang dilakukan kemudian diolah menggunakan rumus statistik. Data yang diperoleh dari hasil perhitungan nilai tertinggi 20 dan nilai terendah 9.

Berdasarkan hasil pengolahan data menggunakan rumus statistik terdapat pada interval pertama yaitu dengan jumlah push-up antara $9-10$ kali terdapat frekuensi siswa sebanyak 3 orang siswa atau dengan persentasi $8 \%$ dari keseluruhan siswa. Pada interval kedua yaitu dengan jumlah push-up antara $11-12$ kali terdapat frekuensi sebanyak 7 atau dengan persentase 18\% dari keseluruhan siswa. Pada interval ketiga yaitu dengan jumlah push-up antara 13 - 14 kali terdapat frekuensi sebanyak 11 atau dengan persentasi $28 \%$ dari keseluruhan siswa. Pada interval keempat yaitu dengan jumlah push up antara 15 - 16 kali terdapat frekuensi sebanyak 9 atau dengan persentasi $23 \%$ dari keseluruhan siswa. Pada interval kelima yaitu dengan jumlah push up antara 17 -18 kali terdapat frekuensi sebanyak 6 atau dengan persentasi 15\% dari keseluruhan siswa. Pada interval keenam dengan jumlah push up antara $19-20$ kali terdapat frekuensi 4 atau dengan persentasi $10 \%$ dari keseluruhan siswa seperti tabel dibawah ini.

Tabel 1.Distribusi Frekuensi Hasil Tes Kekuatan Otot Lengan Pada Siswa SMP Negeri 2 Rambah Samo Kabupaten Rokan Hulu

\begin{tabular}{cccc}
\hline No & Interval & Frekuensi Kumulatif & Frekuensi Relatif \\
\hline 1 & $9-10$ & 3 & $8 \%$ \\
\hline 2 & $11-12$ & 7 & $18 \%$ \\
\hline 3 & $13-14$ & 11 & $28 \%$ \\
\hline 4 & $15-16$ & 9 & $23 \%$ \\
\hline 5 & $17-18$ & 6 & $15 \%$ \\
\hline 6 & $19-20$ & 4 & $10 \%$ \\
\hline & Jumlah & 40 & $100 \%$ \\
\hline
\end{tabular}




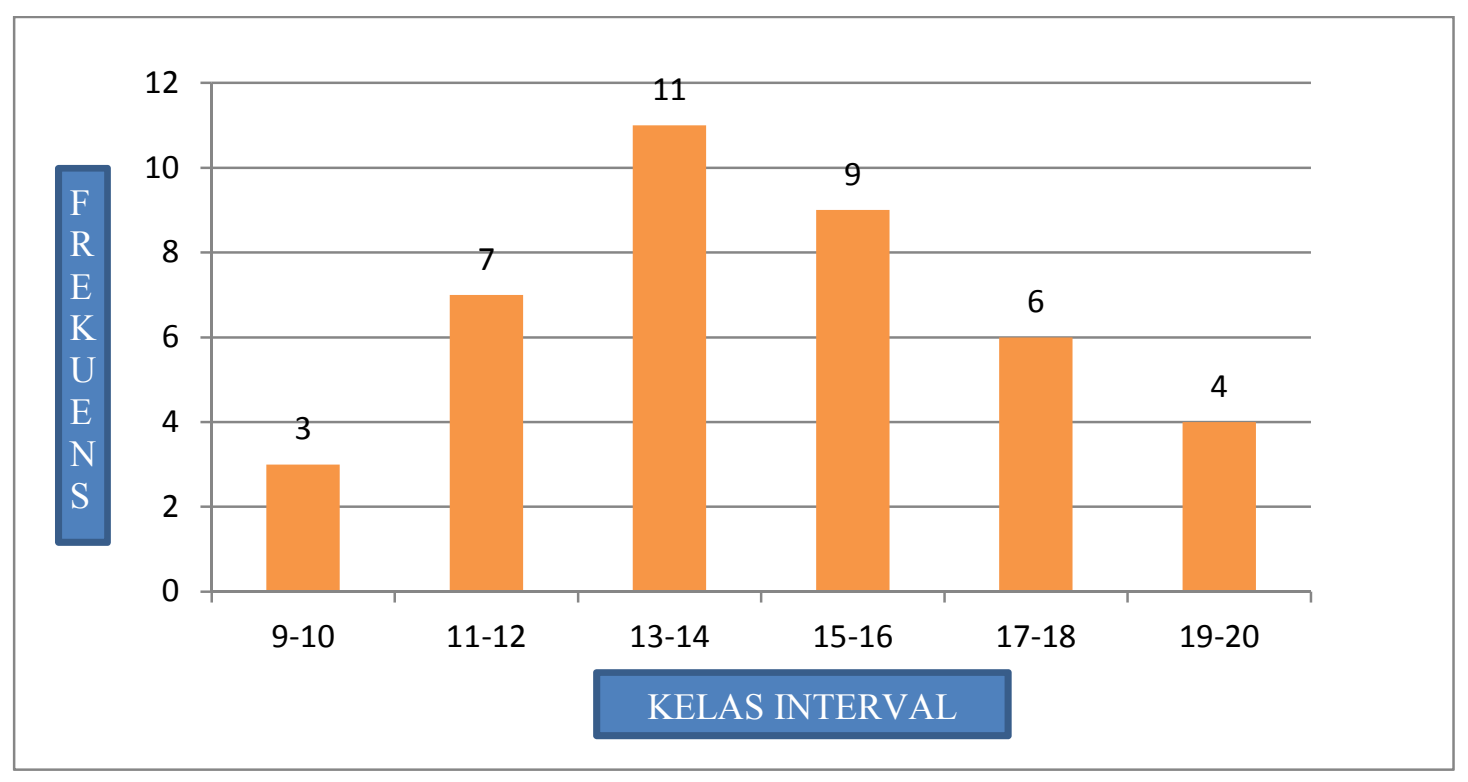

Grafik 1.Grafik Hasil Tes Kekuatan Otot Lengan Siswa SMP Negeri 2 Rambah Samo Kabupaten Rokan Hulu

\section{Data Hasil Tes Kemampuan Servis Bawah SMP Negeri 2 Rambah Samo Kabupaten Rokan Hulu}

Tes yang dilakukan untuk memgetahui kemampuan servis bawah bolavoli adalah dengan menggunakan tes kemampuan servis. Tes ini dilakukan di lapangan bolavoli dengan strategi dengan membagi lapangan menjadi beberapa petak yang memiliki skor yang berbeda-beda. Setiap mendapatkan kesempatan sebanyak 6 kali untuk melakukan servis bawah. Skor servis bawah terbagi menjadi 2 yang tidak dapat dipisahkan. Aspek pertama yaitu bola servis melewati diantara batas tali dan jaring net. Servis dihitung pada saat bola mulai di pukul dan melewati batas atas jaring dan tali, aspek kedua adalah skor angka. Aspek ini dapat di ukur dengan cara melihat pada petak skor tempat bola hasil servis bawah mendarat di lapangan tes. Berdasarkan hasil perhitungan hasil tes servis bawah, peneliti kemudian mengolah menggunakan rumus statistik. Hasil perhitungan di dapatkan skor tertinggi 17 dan skor terendah 7. Untuk lebih jelasnya bisa di lihat di tabel berikut ini :

Berdasarkan hasil pengolahan data menggunakan rumus statistik pada interval pertama yaitu dengan skor servis bawah bolavoli antara $7-8$ terdapat frekuensi siswa sebesar 3 atau dengan persentase 7.5\% dari keseluruhan mahasiswi. Pada interval kedua dengan skor servis bawah bolavoli antara 9-10 terdapat frekuensi siswa sebanyak 7 atau dengan persentase $17.5 \%$ dari keseluruhan siswa. Pada interval ketiga dengan skor servis bawah bolavoli antara 11 - 12 terdapat frekuensi siswa sebanyak 9 atau dengan persentasi $22.5 \%$ dari keseluruhan siswa. Pada interval keempat dengan skor servis bawah bolavoli antara $13-14$ terdapat frekuensi sebanyak 7 atau dengan frekuensi $17.5 \%$ dari keseluruhan siswa. Pada interval kelima dengan skor servis bawah bolavoli antara $15-16$ terdapat frekuensi sebanyak 8 atau dengan frekuensi $20 \%$ dari keseluruhan siswa. Pada interval keenam dengan skor servis bawah bolavoli antara 17 18 terdapat frekuensi sebanyak 6 atau dengan frekuensi 15\%dari keseluruhan siswa terlihat pada tabel di bawah ini. 
Tabel 2. Distribusi Frekuensi Hasil Tes Kemampuan Servis Bawah Bolavoli Pada SMP Negeri 2 Rambah Samo Kabupaten Rokan Hulu

\begin{tabular}{cccc}
\hline No & Interval & Frekuensi Kumulatif & Frekuensi Relatif \\
\hline 1 & $7-8$ & 3 & $7.50 \%$ \\
\hline 2 & $9-10$ & 7 & $17.50 \%$ \\
\hline 3 & $11-12$ & 9 & $22.50 \%$ \\
\hline 4 & $13-14$ & 7 & $17.50 \%$ \\
\hline 5 & $15-16$ & 8 & $20 \%$ \\
\hline 6 & $17-18$ & 6 & $15 \%$ \\
\hline & Jumlah & $\mathbf{4 0}$ & $\mathbf{1 0 0 \%}$ \\
\hline
\end{tabular}

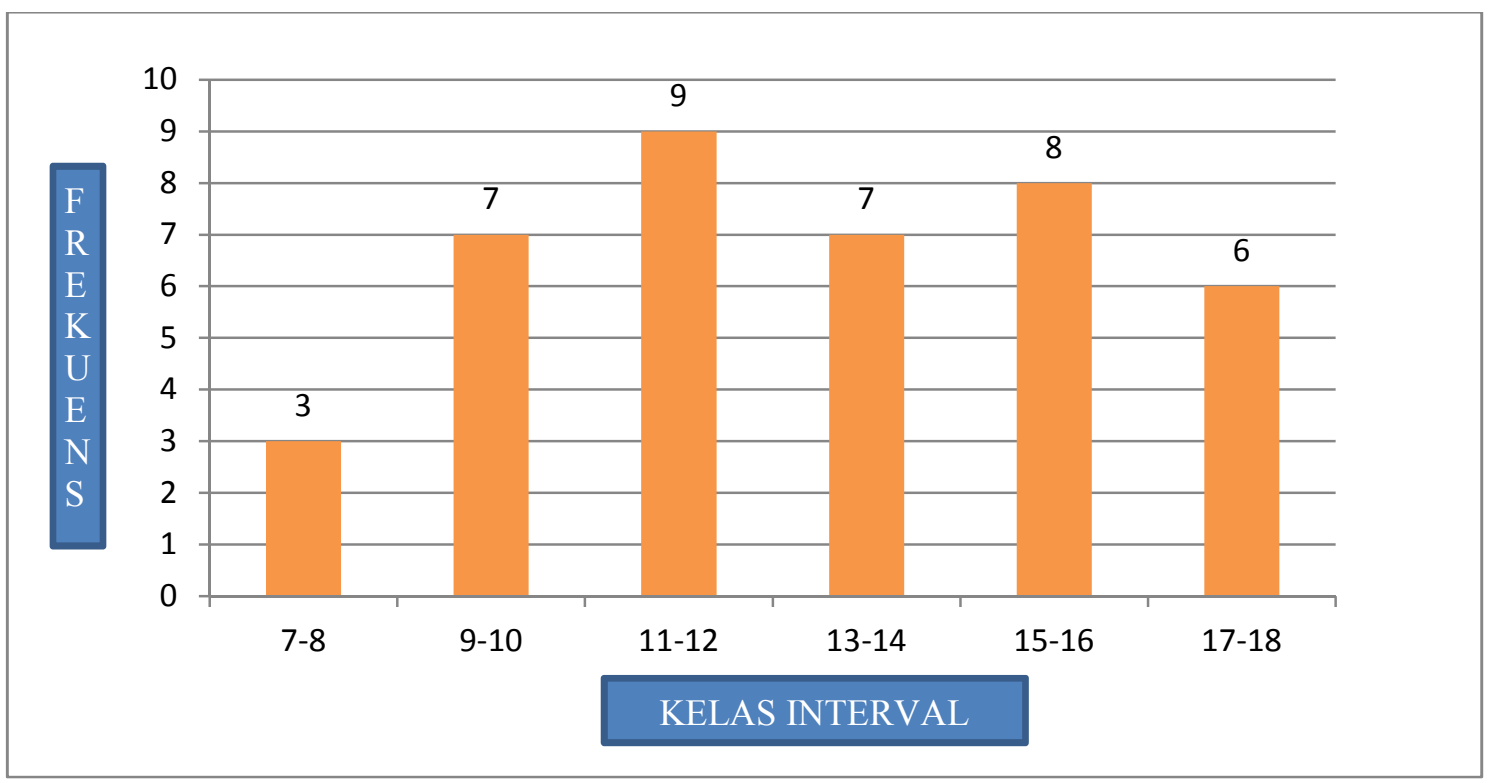

\section{Grafik 2. Grafik Hasil Tes Kemampuan Servis Bawah Bolavoli Siswa SMP Negeri 2 Rambah Samo Kabupaten Rokan Hulu}

Olahraga bolavoli merupakan salah satu olahraga permainan yang bertujuan untuk mendapatkan angka dengan cara memantulkan bola menyeberangi net. Untuk dapat menghasilkan angka atau skor yang dapat dilakukan dengan berbagai cara, dan salah satu cara yang populer dalam olahraga bolavoli adalah dengan melakukan pukulan servis bawah. Servis bawah dalam pertandingan ini bersifat keras dan cepat sehingga sulit didapatkan lawan.

Servis bawah merupakan pukulan awalan dalam memulai pertandingan bolavoli yang dilakukan oleh pemain belakang dan juga dijadikan sebagai serangan awal dalam pertandingan bolavoli dengan pukulan keras dan terarah. Untuk melakukan servis bawah yang baik, juga diperlukan teknik dalam melakukan servis bawah dengan baik. Saat melakukan servis bawah, bola dipegang sejajar perut, lengan harus lurus, saat melakukan pukulan lengan posisi lurus dan ditarik kebelakang sebelum memukul bola. Bola di lambungkan setinggi dada, pergelangan tangan harus tetap kaku, bola di pukul dengan telapak tangan terbuka atau di genggam dan bola dipukul setelah bola berada didepan tubuh. Servis dilakukan dengan pukulan yang tepat, teraarah dan keras 
tujuannya untuk memposisikan bolanya jatuh di tempat yang diinginkan dan tembakan bolanya keras sehingga susah di dapatkan oleh pemain lawan. Dengan demikian semakin keras pukulan servis maka peluang untuk menghasilkan angka saat melakukan servis semakin besar pula.

Untuk menghasilkan pukulan yang keras teknik melakukan servis harus benar dan juga didukung oleh kondisi fisik secara langsung mempengaruhi kemampuan otot adalah kekuatan otot lengan. Seperti di kemukakan oleh Ismaryati, (2006: 111) kekuatan adalah kontraksi otot yang di capai dalam sekali usaha maksimal. Kemampuan kekuatan otot sangat di perlukan bagi atlit olahraga yang membutuhkan gerakan secara cepat dan kuat, misalnya pada saat atlit bolavoli melakukan servis, untuk memukul dengan keras di perlukan kekuatan yang maksimal.

Teori di atas didukung oleh hasil penelitian yang telah dijabarkan sebelumnya. Adapun besar kontribusi kekuatan otot lengan terhadap hasil servis bawah bolavoli mahasiswi semester 2 Penjaskesrek Universitas Islam Riau adalah sebesar 7.06\%. Berdasarkan hasil pengolahan data di peroleh $r_{\text {hitung }}$ sebesar 84.03 sedangkan $r_{\text {tabel }}$ pada taraf signifikan 5\% adalah 0.304 , dari data tersebut, maka uraian tersebut dapat ditarik asumsinya bahwa $r_{\text {hitung }} \geq r_{\text {tabel }}$ atau $84.03 \geq 0.304$.

Faktor yang lain yang berkontribusi terhadap servis bawah antara lain teknik, dimana dalam melakukan servis bawah teknik yang baik akan menghasilkan servis bawah yang baik dan latihan juga dapat meningkatkan kontribusi terhadap kemampuan servis. Koordinasi gerak juga dapat mempengaruhi hasl servis yang baik, apabila koordinasinya baik maka akan baik hasil servis selanjutnya, sarana dan prasarana yang dapat menunjang hasil kegiatan latihan yang lebih baik.

\section{KESIMPULAN}

Kesimpulan yang dapat ditarik dalam penelitian ini adalah terdapat kontribusi kekuatan otot lengan terhadap hasil servis bawah bolavoli siswa SMP Negeri 2 Rambah Samo Kabupaten Rokan Hulu. Berdasarkan hasil pengolahan data di peroleh $\mathrm{r}_{\text {hitung }}$ sebesar 84.03 sedangkan $r_{\text {tabel }}$ pada taraf signifikan $5 \%$ adalah 0.304 , dari data tersebut, maka uraian tersebut dapat ditarik asumsinya bahwa $r_{\text {hitung }} \geq r_{\text {tabel }}$ atau $84.03 \geq 0.304$ Berdasarkan analisis data terdapat indeks kontribusinya sebesar 84.03 dan di uji dengan rumus $\mathrm{KD}$ terdapat hasil kekuatan otot lengan terhadap servis bawah bolavoli siswa SMP Negeri 2 Rambah Samo Kabupaten Rokan hulu sebesar 7.06\% dan hubungannya di katagorikan lemah atau rendah,

\section{DAFTAR PUSTAKA}

Arsil, dan Adnan. 2010. Evaluasi Pendidikan Jasmani dan Olahraga, Padamg: Wideka Media.

Erianti, 2011. Buku Ajar Bola Voli. Padang : Falkutas Ilmu Keolahragaan Universitas Negeri Padang.

Ismaryati, 2006. Tes dan Pengukuran Olahraga, Surakarta: LLP dan Percetakan UNS 
Nurhasan, 2001. Tes dan Pengukuran Dalam Pendidikan Jasmani, Jakarta: Direktorat Jendral Olahraga.

Syafruddin, 2013. Ilmu Kepelatihan Olahraga, Padang: Falkutas Ilmu Keolahragaan Universitas Negeri Padang.

Sujarwo Suhardi. 2009. Volleyball For All / Bola Voli Untuk Semua. Yogyakarta. 